\title{
Epiphytic macrolichens in Seoul: 35 years after the first lichen study in Korea
}

\author{
Chorong Ahn ${ }^{1,3}$, Eunmi Chang ${ }^{2}$ and Hyesoon Kang ${ }^{1, *}$ \\ ${ }^{1}$ School of Biological Science and Chemistry, Sungshin Women's University, Seoul 142-732, Korea \\ ${ }^{2}$ Ziin Consulting Institute, Seoul 110-070, Korea \\ ${ }^{3}$ Present Address: Department of Forest Conservation, Korea Forest Research Institute, Seoul 130-712, Korea
}

\begin{abstract}
Many lichens have been used as bioindicators for air pollutants such as $\mathrm{SO}_{2}$. The first ecological study on lichens in Korea was conducted in 1975 by Kim and Lee, disclosing that areas adjacent to the center of Seoul were lichen deserts. Air quality in Seoul has improved significantly since the 1980s. However, the distribution of lichen species has not been reevaluated since then. We examined the spatial and temporal pattern of lichen distribution by selecting six (inner city green [ICG] and four (outer city green [OCG]) sites, based on the distance from the city center of Seoul and the land use pattern. The change in lichen distribution was related to yearly mean concentrations of $\mathrm{SO}_{2}, \mathrm{NO}_{2}$, and $\mathrm{O}_{3}$ for the years 1980-2009. Four and 13 lichen species were found in ICGs and OCGs, respectively. Although mean sample numbers per species were much higher in the former, species richness tended to increase with distance from the city center. Since $1980, \mathrm{SO}_{2}$ has declined drastically to $<0.01 \mathrm{ppm}$ in both ICGs and OCGs, indicating that $\mathrm{SO}_{2}$ is no longer a limiting factor for lichen establishment and growth. In contrast, $\mathrm{NO}_{2}$ has increased steadily for 20 years (1989-2009) and a considerable proportion of lichen species in both ICGs and OCGs are known as nitrophilic or pollution-tolerant species. Appearance of nitrophiles in both ICGs and OCGs and the dominance of a few lichen species in ICGs may reflect the effects of the increase in $\mathrm{NO}_{2}$. In contrast to $\mathrm{SO}_{2}$ and $\mathrm{NO}_{2}, \mathrm{O}_{3}$ was higher in OCGs, but it was difficult to identify a causal relationship between $\mathrm{O}_{3}$ and lichen distribution.
\end{abstract}

Key words: air pollutants, bioindicator, lichens, Seoul, temporal and spatial variation

\section{INTRODUCTION}

Air pollutants clog urban cities; thus, it is difficult to judge the quality of the atmosphere with just a few components. In this case, we can judge air quality by analyzing the response of species to several air pollutants in consideration. In particular, epiphytic macrolichens on tree bark are excellent air pollution bioindicators. For example, they receive nutrition and moisture through the thallus surface, and they have long lives. They also are able to concentrate pollutants, because they do not have cuticles and deciduous parts (Nash 2008). Therefore, epiphytic macrolichens have been used as air pollution bioindicators since lichen extinction was first observed in Paris (Nylander 1866, cited in Hawksworth and Rose 1970).

Until the mid-late 20th century, many studies revealed that a high concentration of $\mathrm{SO}_{2}$ disturbs the growth of lichens (Hawksworth and Rose 1970, Sugiyama et al. 1976, Eversman 1978, McCune 1988, Nimis et al. 1990). Results of these studies also indicated that lichen loss was con-

\section{Open Access http://dx.doi.org/10.5141/JEFB.2011.040}

This is an Open Access article distributed under the terms of the Creative Commons Attribution Non-Commercial License (http://creativecommons. org/licenses/by-nc/3.0/) which permits unrestricted non-commercial use distribution, and reproduction in any medium, provided the original work is properly cited. pISSN: 1975-020X eISSN: 2093-4521
Received 08 August 2011, Accepted 09 September 2011

*Corresponding Author

E-mail: hkang@sungshin.ac.kr

Tel: +82-2-920-7475 
spicuous near the city center or pollution sources. For example, 129 lichen species within $16 \mathrm{~km}$ of London became extinct between 1800 and 1970 (Laundon 1970). Conversely, the number of lichen species tended to increase with distance from the city center. In a study in London, Rose and Hawksworth (1981) showed that areas in the atmosphere with $\mathrm{SO}_{2}>0.04 \mathrm{ppm}\left(120-130 \mu \mathrm{g} / \mathrm{m}^{3}\right)$ were lichen deserts where lichen existence was impossible. Interestingly, lichens are recolonizing areas that used to be lichen deserts (Henderson-Sellers and Seaward 1979, Rose and Hawksworth 1981, Hawksworth and McManus 1989, Bates et al. 1990, Seaward 1997).

Although $\mathrm{SO}_{2}$ has decreased recently, nitrogen oxides (NOx) such as $\mathrm{NO}$ and $\mathrm{NO}_{2}$, and $\mathrm{O}_{3}$ have been increasing. The change in air pollutants has been accompanied by a decrease in Lecanora conizaeoides in North America and Europe, which is an $\mathrm{SO}_{2}$-tolerant species (Bates et al. 2001, Hauck et al. 2001), as well as an increase in pollutiontolerant species such as Phaeophyscia orbicularis, Physcia adescendens, and Xanthoria parietina (Seaward 1997) and nitrophilic species such as Candelaria concolor and Phaeophyscia rubropulchra (Sigal and Nash 1983, de Bakker 1989, Jovan and McCune 2005). Furthermore, global warming acts as a new threat to symbiotic lichens (Geiser and Neitlich 2007). Reports of changes in lichen distribution and air quality are occurring simultaneously in urban and natural environments, suggesting that multi-disciplinary approaches to lichens are necessary.

According to the first ecological study on Korean lichens by Kim and Lee (1975), areas within $5 \mathrm{~km}$ of Gwanghwamun (city center hereafter) were lichen deserts. By 1991, this area expanded to $15 \mathrm{~km}$ from the city center and coincided with areas that had an $\mathrm{SO}_{2}$ concentration $>0.01 \mathrm{ppm}$ (Kim 1991). Considering the phytotoxic effects of $\mathrm{SO}_{2}$ on lichens, their results revealed that air quality in Seoul was quite poor from 1970-1980. However, the Clean Air Act was enacted in 1990, leading to a decrease in $\mathrm{SO}_{2}$ concentration in Seoul. Specifically, the concentration has decreased after 1991 to $<0.04 \mathrm{ppm}$ and has been maintained < $0.01 \mathrm{ppm}$ since 1998 (Ministry of Environment 2010). Assuming $0.04 \mathrm{ppm} \mathrm{SO}_{2}$ as a tolerance limit, it would take approximately 5 years for an epiphytic lichen on rocks such as Lecanora muralis to establish in an environment (Henderson-Sellers and Seaward 1979). If so, the lichens that became extinct due to their $\mathrm{SO}_{2}$ sensitivity could have become reestablished by now in Seoul.

In Korea, lichen studies have been conducted on the distribution in relation to pollution centers (Lee et al. 1993, 1994, Yu et al. 1995, Chu and Kim 1998, Kim and Kang 2001), selection of bioindicator species in response to air pollution sources (Hur and Kim 2000), and taxonomic diversity (Park 1990, Ka et al. 1997, Moon 1998). However, the extent of lichen studies is very limited. Thus, analyses have not been conducted on whether lichens have established themselves in inner city greens (ICGs), and, if they have, what species have done so, what lichens exist outside the city, and what the species composition and richness are in comparison to Kim and Lee (1975). The spatial and temporal patterns of lichen distribution are critical data to set standards for Seoul's atmosphere policy and for an overall evaluation of nature conservation policy.

In this study, we attempted to solve the following questions: 1) In Seoul, do species composition and richness differ between inner and outer city greens (OCGs)?; 2) Are there any changes in species composition and richness since the initial study conducted 35 years ago?; 3) Are the particular lichens' temporal and spatial distributions related to the level of $\mathrm{SO}_{2}, \mathrm{NO}_{2}$, or $\mathrm{O}_{3}$ ?

\section{MATERIALS AND METHODS}

\section{Study sites and sampling}

Seoul is located in the center of the Korean Peninsula $\left(126^{\circ} 59^{\prime \prime} \mathrm{E}, 37^{\circ} 34^{\prime \prime} \mathrm{N}\right)$ and is $30.30 \mathrm{~km}$ long and $36.78 \mathrm{~km}$ across with a total area of $605.52 \mathrm{~km}^{2}$. The Han River flows through the center of the city, crossing in a west to east direction. Namsan stands close to the center of the city. Twenty-six mountains border the edge of the city (Seoul Metropolitan Government 2010). According to climate data (30 year average from 1971-2000), Seoul's mean temperature is $12.2^{\circ} \mathrm{C}$, relative humidity is $66.8 \%$, yearly rainfall is $1,344 \mathrm{~mm}$, and yearly mean wind speed is $2.4 \mathrm{~m} / \mathrm{s}$ (Korea Meteorological Administration 2001).

Lichen investigations were conducted in areas that matched the following three criteria: 1 ) green areas located 5, 10, 15, and $20 \mathrm{~km}$ from the city center; 2) areas that were formed long enough ago for lichens to have become established; 3 ) areas where studies have been conducted previously, so that temporal comparisons would be possible. Consequently, we selected the following ten sites, six within and four outside a $10 \mathrm{~km}$ radius from the city center (Fig. 1). Six ICGs (Boramae Park, Chandeokgung, Dosan Park, Namsan Park, Samnung Park, and Sangdo Park) were selected from parks and palaces with long histories of greens located in areas with a relatively high level of air pollution (Oh and Chung 2007). Four OCGs (Bukhansan, Cheonggyesan, Gwanaksan, and Suraksan) 


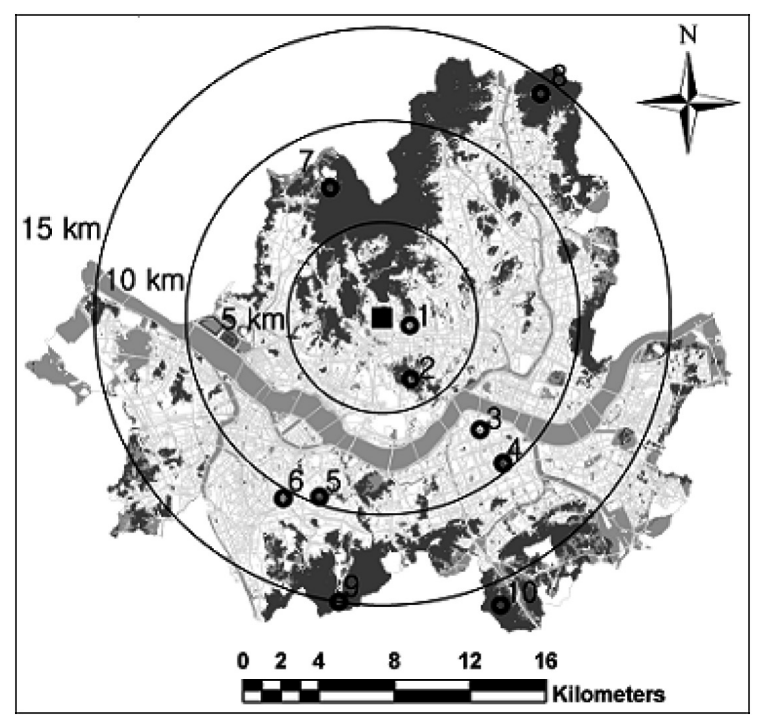

Fig. 1. Location of the city center $(\boldsymbol{\square})$ and ten study sites in Seoul, Korea. Numbers represent sites: 1, Chandeokgung; 2, Namsan; 3, Dosan Park; 4, Samnung Park; 5, Boramae Park; 6, Sango Park; 7, Bukhansan; 8, Suraksan; 9, Gwanaksan; 10, Cheonggyesan.

were chosen from outer Seoul. Bukhansan is located within $10 \mathrm{~km}$ from the city center but is treated as an OCG because of its ecological value as a national park.

We collected epiphytic macrolichens on tree bark in May-June 2010. We searched entire trails for ICGs and investigated trees on some of the hiking paths for the OCGs. We spent almost similar time sampling at each site. Sampling was conducted $<2 \mathrm{~m}$ from the ground, largely in the southern part of trees ranging from the southeast to southwest sides. ICG samples were taken from an average of 6.4 tree species per site, e.g., Zelcova serrata, Ginkgo biloba, and Acer palmatum, whereas OCGs were from an average of 4.0 tree species per site, e.g., Pinus densiflora, P. rigida, and $Z$. serrata. Finally, we collected 133 samples: 84 from ICGs and 49 from OCGs. The lichens we obtained were stored at $-20^{\circ} \mathrm{C}$ until they were prepared as specimens. We rinsed the samples with distilled water and removed extraneous material to prepare the specimens. Then, we dried the samples with dry towels and compressed lightly in old newspaper. The specimens were finally prepared by repeating the drying/compressing procedure. Specimens were stored in Sungshin Women's University Plant Herbarium. Although some previous studies (e.g., Kim and Kang 2001) included lichens on various substrates, we decided to focus on epiphytic macrolichens on tree bark. The species of lichens were confirmed using monographs (Hale 1969, Yoshimura 1994, Brodo et al. 2001). We used new names for cases in which the lichen species name had been changed. For example, Cladonia bacillaris was changed to C. macilenta.

\section{Lichen identification}

Specimens were identified based on exterior characteristics and a chemical composition analysis. We examined the thallus and reproductive structures and conducted chemical analyses following the color test (Nylander 1866), microcrystal tests (Asahina 1937), and thin layer chromatography (Culberson 1972).

\section{Data analysis}

Following LeBlanc and De Sloover (1970), we calculated the ecological index, $Q$, to reflect the number of species coexisting with a particular lichen species at each site:

$$
Q=\frac{\sum S n_{i}}{S n}
$$

where $S n$ indicates the number of sites in which a certain species appeared, and $S n_{i}$ indicates the number of species coexisting with that species at a particular site. The spatial pattern of lichen distribution was examined by comparing lichen species collected at ICGs and OCGs in 2010. The relationship between lichen abundance and types of greens (ICGs and OCGs) was tested using the $\mathrm{X}^{2}$ test for the four abundant species with samples $\geq 8$ (Candelaria concolor, Cladonia macilenta, Phaeophyscia hispidula, and Physciella melanchra). We used the Pearson's correlation analysis to understand the lichen distribution patterns with respect to the distance from the city center. We compared these results with lichens examined in previous studies to examine the lichen temporal distribution pattern (e.g., Kim and Lee 1975) to the 2010 data.

We obtained data on air pollutants $\left(\mathrm{SO}_{2}, \mathrm{NO}_{2}\right.$, and $\left.\mathrm{O}_{3}\right)$ during the past 20 years (1989-2009; 1980-2009 for $\mathrm{SO}_{2}$ ) (Ministry of Environment 2010). Air quality monitoring in Seoul began at ten stations in 1989 but has been conducted at 27 stations since 1998. We used the data from the station closest to each site, and when there were two stations close to the same site (e.g., Changdeokgung and Namsan), we used the mean values. To determine whether significant changes occurred in air quality since 1989, we conducted paired $t$-test analyses to compare the air pollutant levels between the initial three years (1989-1991) versus the recent three years (2007-2009) using overall means derived from all stations in Seoul. Most ICGs were close to roads and a number of people passed by the areas, leading to little difference between values re- 
corded from stations nearby. Thus, in the case of the ICGs, we obtained both the initial and recent 3-year mean data for $\mathrm{SO}_{2}, \mathrm{NO}_{2}$, and $\mathrm{O}_{3}$ from nearby stations. Indeed, four ICGs had 20 years of data. In contrast, even the closest station recorded significantly different values from values recorded within forests in the case of OCGs (Yoo 2008). Only two (Bukhansan since 1999, Gwanaksan since 2009) of the four OCGs had stations within forests, and we used the 3-year mean data derived from stations within the forests. We conducted the Wilcoxon two-sample test to identify the relationship between Seoul's ICG and OCG air quality and species richness; the significance of the $t$ and $Z$ statistics was examined with a one-tailed test.

\section{RESULTS}

\section{Lichen spatial distribution pattern}

The 133 epiphytic macrolichens collected from ten sites were composed of four families, seven genera, and 13 species (Table 1). The 84 samples collected from six
ICGs were composed of four species from two families with a mean of 2.5 species per site (range, 2 to 3 species) and a mean of 21 samples per species. With the exception of Candellaria concolor (Candelariaceae), the other three species belonged to Physciaceae and mostly coexisted in ICGs. Although C. concolor only appeared in Bukhansan, the other three species were found together in at least two OCGs. Therefore, although the ICG species richness was quite low, little difference in species composition was observed with the exception of Phaeophscia rubropulchra.

In the OCGs, there were 49 samples (13 species in four families) with means of 12 samples and 5.5 species per site (range, 2 to 8 species) and a mean of 3.8 samples per species. In addition to the two families observed in the ICGs, two additional families (Cladoniaceae and Parmeliaceae; three and six species each) were observed as well. Of these nine species, Cladonia macilenta and Myelochroa aurulenta were found in almost all OCGs, whereas the other species were found only at particular sites. Overall, Bukhansan (eight species), Suraksan (seven species), and Cheonggyesan (five species) all had species richness twice as high as that of the ICGs, whereas Gwa-

Table 1. Lichen species and the number of lichen samples collected at each site in Seoul

\begin{tabular}{|c|c|c|c|c|c|c|c|c|c|c|c|}
\hline & \multicolumn{6}{|c|}{ Inner city green } & \multicolumn{4}{|c|}{ Outer city green } & \multirow[b]{2}{*}{$Q$} \\
\hline & $\begin{array}{c}\text { Boramae } \\
\text { Park } \\
(9.8)\end{array}$ & $\begin{array}{c}\text { Changdeok } \\
\text {-gung } \\
\text { (1.5) }\end{array}$ & $\begin{array}{c}\text { Dosan } \\
\text { Park } \\
(7.7)\end{array}$ & $\begin{array}{c}\text { Namsan } \\
\text { Park } \\
(2.9)\end{array}$ & $\begin{array}{c}\text { Samnung } \\
\text { Park } \\
(9.8)\end{array}$ & $\begin{array}{c}\text { Sangdo } \\
\text { Park } \\
(10.4)\end{array}$ & $\begin{array}{c}\text { Bukhan } \\
\text {-san } \\
(7.2)\end{array}$ & $\begin{array}{c}\text { Cheong } \\
\text {-gyesan } \\
\text { (16) }\end{array}$ & $\begin{array}{c}\text { Gwanak } \\
\text {-san } \\
(14.8)\end{array}$ & $\begin{array}{c}\text { Surak } \\
\text {-san } \\
(18)\end{array}$ & \\
\hline \multicolumn{12}{|l|}{ Candelariaceae } \\
\hline Candelaria concolor & 2 & 2 & 1 & 1 & 1 & & 1 & & & & 3.67 \\
\hline \multicolumn{12}{|l|}{ Cladoniaceae } \\
\hline Cladonia chlorophaea & & & & & & & & & 3 & & 2 \\
\hline Cladonia macilenta & & & & & & & 3 & 3 & 8 & 5 & 5.5 \\
\hline Cladonia ochrochlora & & & & & & & & & & 1 & 7 \\
\hline \multicolumn{12}{|l|}{ Parmeliaceae } \\
\hline Myelochroa aurulenta & & & & & & & 1 & 2 & & 1 & 6.67 \\
\hline Myelochroa entotheiochroa & & & & & & & & & & 1 & 7 \\
\hline Myelochroa hayachinensis & & & & & & & 1 & & & & 8 \\
\hline Myelochroa irrugans & & & & & & & & & & 1 & 7 \\
\hline Parmotrema clavuliferum & & & & & & & 1 & & & & 8 \\
\hline Punctelia rudecta & & & & & & & 1 & & & & 8 \\
\hline \multicolumn{12}{|l|}{ Physciaceae } \\
\hline Phaeophyscia hispidula & 1 & 3 & & & 7 & 1 & & 3 & & 1 & 3.83 \\
\hline Phaeophyscia rubropulchra & & & & 1 & & & 1 & 3 & & & 5.33 \\
\hline Physciella melanchra & 13 & 13 & 15 & 9 & 10 & 5 & 1 & 2 & & 4 & 4 \\
\hline Species richness & 3 & 3 & 2 & 3 & 3 & 2 & 8 & 5 & 2 & 7 & \\
\hline
\end{tabular}

Ecological index $Q$ is provided for each species. Distance $(\mathrm{km})$ from the city center of Seoul is indicated within parentheses. 


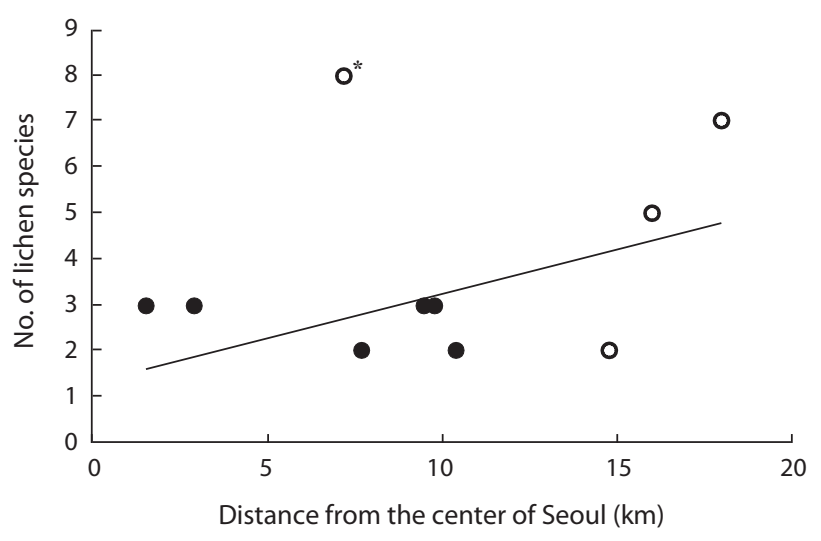

Fig. 2. Relationship between the number of lichen species found at each site and its distance from the center of Seoul $(r=0.34, P=0.3402)$. A regression line was drawn to indicate the linear trend upon deleting a single outlier site with an asterisk (Bukhansan). $\bullet$, inner city green; $\circ$, outer city green.

naksan only had two congeneric species (C. chlorophaea and C. macilenta).

The abundance per site of the four most abundant species (Candelaria concolor, Cladonia macilenta, Phaeophyscia hispidula, and Physciella melanchra) was not much different between the ICGs and OCGs (mean number of samples $=14.2$ vs. 12.0). However, there was a tendency that a particular species occurred at a certain site $\left(\mathrm{X}^{2}=\right.$ 63.23, $P<0.0001, N=115)$. C. macilenta was not found in ICGs, but was found four times more than the expected value of the OCGs. P. melanchra was found in both ICGs and OCGs, comprising $54.1 \%$ of the samples. However, it occurred slightly more frequently than the expected value in ICGs, and much less than that of OCGs. Species (except for C. macilenta) found only in OCGs were usually only spotted once per site. The ecological index, $Q$, was as low as 2 (C. chlorophaea) to 8 (M. hayachinensis, P. clavuliferum, and P. rudecta) (Table 1). With the exception of $C$. chlorophaea, which was only found in Gwanaksan, species that appeared in OCGs had a higher $Q$ (range, 5.5 to
8) than those found in both OCGs and ICGs (range, 3.67 to 5.33$)$.

The distance from the city center was not significantly correlated with species richness $(r=0.34, P=0.3402)$. However, excluding Bukhansan, the tendency for increasing species richness with distance from the city center was marginally significant $(\mathrm{Y}=0.191 \mathrm{X}+1.310, r=0.63, P$ $=0.0719)$ (Fig. 2).

\section{Lichen temporal distribution pattern}

Some of the ten sites examined in this study had also been studied in previous studies (Table 2). Three lichen species each were found in ICGs such as Chandeokgung and Namsan, which were previously lichen deserts. C.concolor and P. melanchra were found at both sites, whereas Parmotrema clavuliferum and Phaeophyscia rubropulchra were present at only one site (Table 1). Just two OCG species (Cladonia macilenta and C. chlorophaea) were observed in Gwanaksan, eight in Bukhansan, and seven in Suraksan, which was more (one species reported in Suraksan [Lee et al. 1994]) or less (17 species reported in Bukhansan [Moon 1998]) than previous studies (Table 3). Thus, five of the eight species in Bukhansan were common in this study and that of Moon (1998). In contrast, only a single species of the seven species in Suraksan was also found in Lee et al. (1994) (Table 3).

\section{Change in $\mathrm{SO}_{2}, \mathrm{NO}_{2}$, and $\mathrm{O}_{3}$ atmospheric concen- trations}

Fig. 3 shows that the mean concentrations of air pollutants in Seoul have changed greatly with time. $\mathrm{SO}_{2}$ was $0.094 \mathrm{ppm}$ in 1980 but decreased drastically to $0.006 \mathrm{ppm}$ after 2000 , just $6 \%$ of 1980 , and has been maintained at a similar level since that time. $\mathrm{NO}_{2}$ was $0.027 \mathrm{ppm}$ in 1989 but increased 1.3 times by 2009 to $0.035 \mathrm{ppm}$. During the same period, $\mathrm{O}_{3}$ increased 2.6 times, from $0.008 \mathrm{ppm}$ to

Table 2. Record of sites examined in lichen studies in Seoul since 1975

\begin{tabular}{|c|c|c|c|c|c|c|c|c|c|c|}
\hline & \multicolumn{6}{|c|}{ Inner city green } & \multicolumn{4}{|c|}{ Outer city green } \\
\hline & $\begin{array}{c}\text { Boramae } \\
\text { Park }\end{array}$ & $\begin{array}{l}\text { Chang } \\
\text {-deokgung }\end{array}$ & $\begin{array}{c}\text { Dosan } \\
\text { Park }\end{array}$ & $\underset{\text { Park }}{\text { Namsan }}$ & $\underset{\text { Park }}{\text { Samnung }}$ & $\begin{array}{c}\text { Sangdo } \\
\text { Park }\end{array}$ & $\begin{array}{c}\text { Bukhan } \\
\text {-san }\end{array}$ & $\begin{array}{c}\text { Cheonggye } \\
\text {-san }\end{array}$ & $\begin{array}{c}\text { Gwanak } \\
\text {-san }\end{array}$ & $\begin{array}{c}\text { Surak } \\
\text {-san }\end{array}$ \\
\hline Kim and Lee 1975 & & + & & + & & & + & & + & \\
\hline Lee et al. 1993 & & & & + & & & & & + & \\
\hline Lee et al. 1994 & & & & & & & & & & + \\
\hline Moon 1998 & & & & & & & + & & & \\
\hline
\end{tabular}

+ indicates sites that were also examined in this study. 


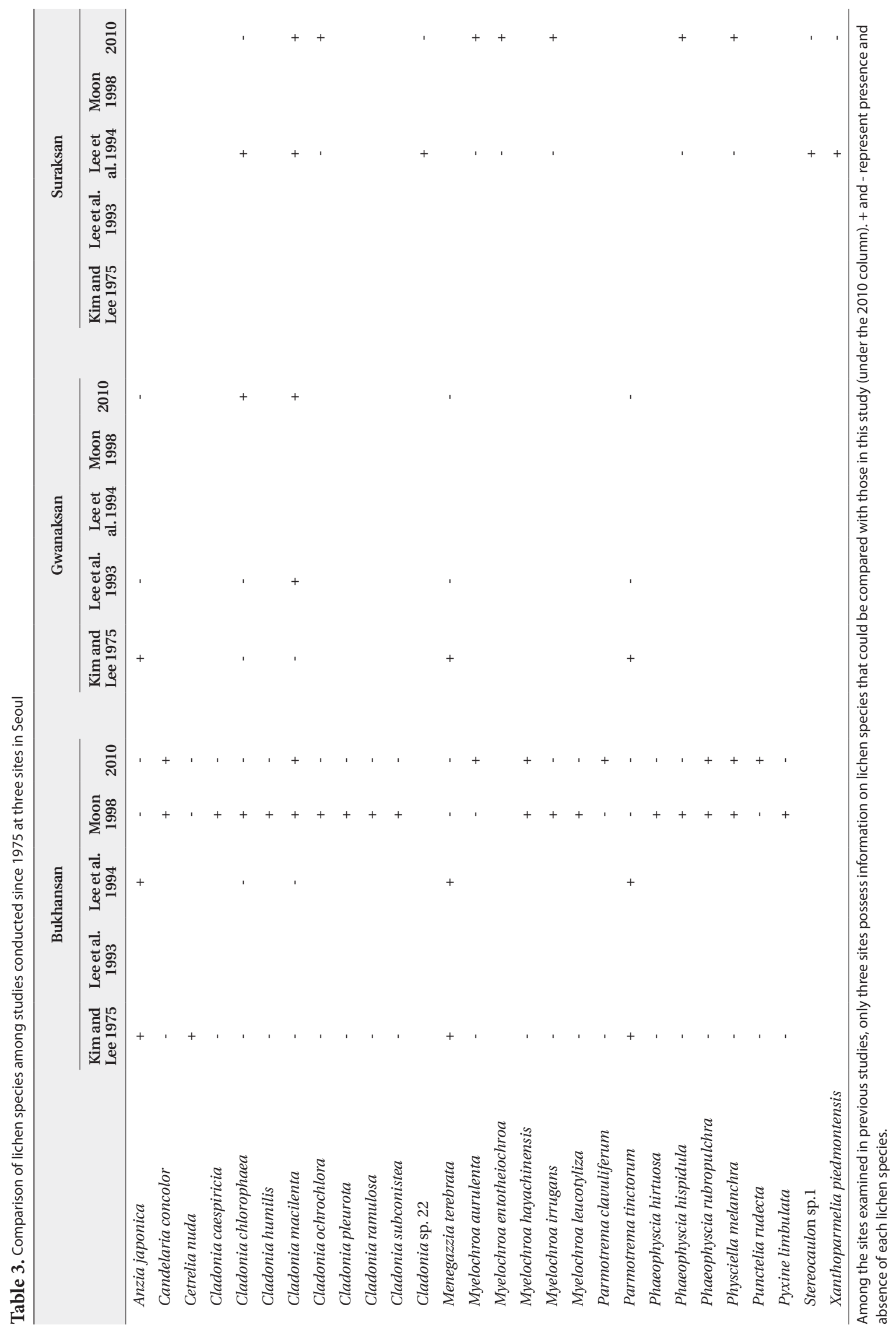




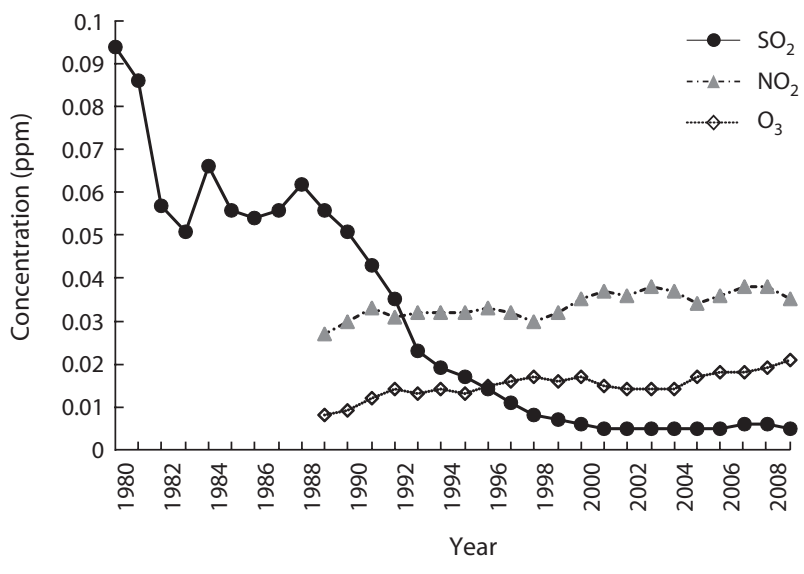

Fig. 3. Mean concentration (ppm) of air pollutants in Seoul from 1989 to 2009 (1980 to 2009 for $\mathrm{SO}_{2}$ ).
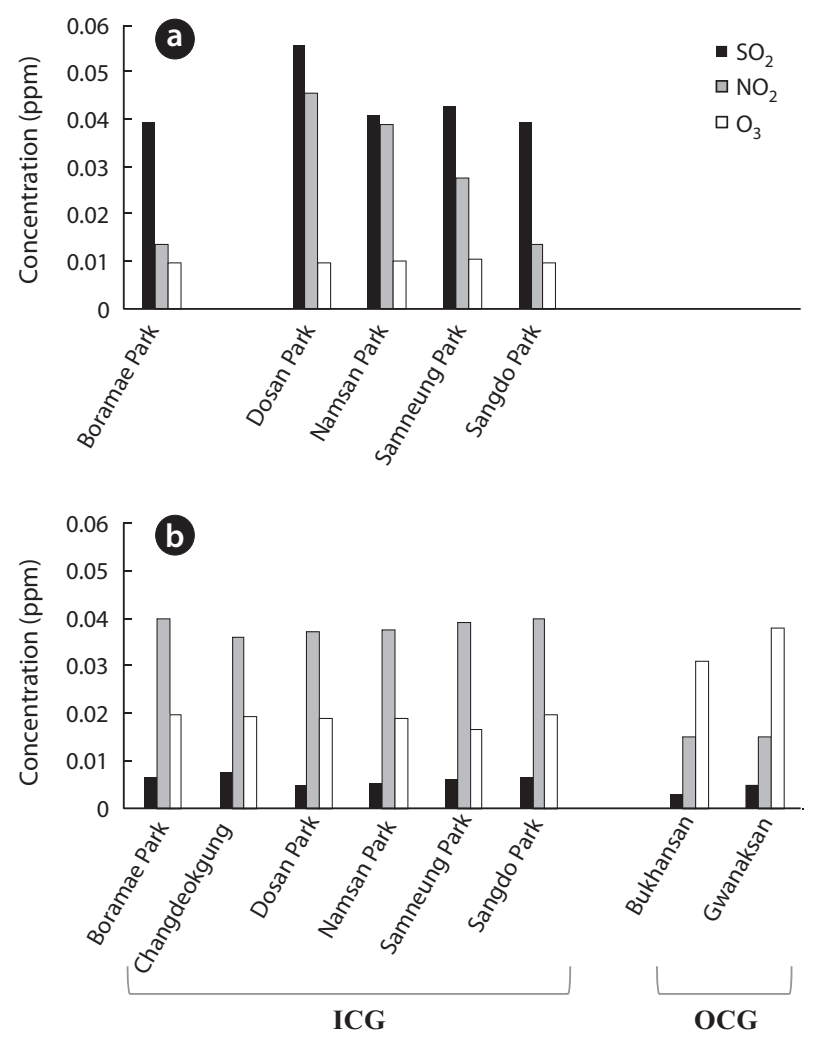

Fig. 4. Mean concentration (ppm) of air pollutants (a) during the initial 3 years (1989-1991) at the four inner city greens (ICGs) and (b) during the recent 3 years (2007-2009) at the six ICGs and two outer city greens (OCGs).

$0.021 \mathrm{ppm}$. Comparing data from the initial 3 years to the recent 3 years, $\mathrm{SO}_{2}$ was the only pollutant that decreased (paired $t$-test: $t=9.45, P<0.0001) . \mathrm{NO}_{2}$ increased marginally $(t=-2.11, P=0.0543)$ and $\mathrm{O}_{3}$ increased significantly $(t=-15.20, P<0.0001)$. Considering only four ICGs with 20 year records of air pollutants, the temporal pattern of air pollutants was similar to that based on the overall means in Seoul $\left(\mathrm{SO}_{2} t=7.16, P=0.0056 ; \mathrm{O}_{3} t=-11.74, P=\right.$ 0.0013) (Fig. 4a). Yet the marginal significance of the $\mathrm{NO}_{2}$ increase disappeared most likely due to small sample size $(t=-0.63, P=0.5755)$.

The recent 3-year mean concentrations of air pollutants differed slightly or considerably between the ICGs and OCGs (Fig. 4b). Regardless of green type, $\mathrm{SO}_{2}$ concentration decreased greatly compared to that in the 1980s. However, it was still slightly higher in ICGs than in OCGs (Wilcoxon two-sample test $Z=-1.51, P=0.0656 ; 0.006 \pm$ $0.0010 \mathrm{ppm}$ vs. $0.004 \pm 0.0012 \mathrm{ppm})$. $\mathrm{NO}_{2}$ concentration was 2.5 times higher in ICGs than that in OCGs $(Z=-1.84$, $P=0.0326 ; 0.038 \pm 0.0017$ ppm vs. $0.015 \pm 0.0002$ ppm). In comparison, $\mathrm{O}_{3}$ concentrations were 1.8 times higher in OCGs than in ICGs $(Z=1.86, P=0.0318 ; 0.019 \pm 0.0011$ ppm vs. $0.034 \pm 0.0052 \mathrm{ppm})$.

\section{DISCUSSION}

This study examined the spatial and temporal changes in lichen distribution by reevaluating the first ecological research on Korean lichens (Kim and Lee 1975). Our results showed that lichens have re-established themselves in ICGs of Seoul, which had been a lichen desert until 1991. However, despite the reestablishment of lichens in ICGs, these are more monotonous in terms of species composition and are lower in species richness than OCGs. For example, four species (2-3 species per site) were found in ICGs, whereas 13 species (5-8 species per site) were observed in OCGs, except for Gwanaksan. Consequently, OCGs such as Bukhansan, Cheonggyesan, and Suraksan possess twice higher species richness than that of the ICGs. An increase in species richness as distance from pollution sources increases has also been observed in other cities in Korea, e.g., Ulsan (Chu and Kim 1998), Yeochun Industrial Estate (Yu et al. 1995), Chongju (Kim and Kang 2001), and Samchonpo Thermoelectric Power Plant (Kim et al. 2004). However, it should be noted that there were significant differences in species composition in the OCGs compared with those in previous studies (Table 3). Such differences either may reflect that air quality is improving (Chu and Kim 1998) or that there is a difference in sampling intensity or species identification among studies. Unfortunately, the specimens from previous studies were not stored; thus, it is impossible to discuss these possibilities.

The distance from Seoul city center does not account completely for lichen species richness. Although 
Bukhansan is very close to the city center, it exhibited a relatively higher level of species richness. If lichens are more abundant in old-growth forest than in young forests, and in continuous rather than in fragmented forests (Marmor et al. 2011), we believe that Bukhansan, which is a national park, may provide sufficient habitat for a number of lichens. In contrast, lichen species richness in Gwanaksan was quite low in this study, which agreed with previous studies (Kim and Lee 1975, Lee et al. 1993). As all lichen samples in Gwanaksan were obtained from red pines, low species richness may reflect that red pines with strongly acid bark do not support diverse lichens.

Most lichens are very sensitive to air pollutants, particularly $\mathrm{SO}_{2}$ (Hawksworth and Rose 1970, Sigal and Nash 1983, van Dobben and ter Braak 1998, Bates et al. 2001). However, as $\mathrm{SO}_{2}$ concentration decreases, lichen species re-establish themselves, whereas species that have a high requirement for sulfur such as Lecanora conizaeoides tend to decrease in abundance (Henderson-Sellers and Seaward 1979, Bates et al. 2001, Hauck et al. 2001). For example, six lichen species in London that were considered extinct for 200 years were found again between 1953 and 1967 (Rose and Hawksworth 1981). Based on the growth rate of lichens, they concluded that the lichens re-established themselves as $\mathrm{SO}_{2}$ decreased to $50 \%$ of their pre1960 levels or to approximately $0.04 \mathrm{ppm}$. According to another study, it takes approximately 5 years for epiphytic lichen on rocks, such as Lecanora muralis, to re-establish at the same concentration (Henderson-Sellers and Seaward 1979). Kim (1991) suggested that the concentration limit for lichens is $0.01 \mathrm{ppm} . \mathrm{SO}_{2}$ concentration in Seoul has decreased drastically from $0.094 \mathrm{ppm}$ in the $1980 \mathrm{~s}$ to 0.04 ppm post-1992 and has been maintained at a level $<0.01 \mathrm{ppm}$ since 1998. However, $\mathrm{SO}_{2}$ concentration in both ICGs and OCGs is far lower than $0.04 \mathrm{ppm}$ (Rose and Hawksworth 1981), 0.02 ppm (Sugiyama et al. 1976), or $0.01 \mathrm{ppm}$ (Kim 1991). Therefore, the $\mathrm{SO}_{2}$ concentration in Seoul may not function as a main factor limiting lichen existence, because sufficient time has passed for lichens sensitive to $\mathrm{SO}_{2}$ to distribute and re-establish. Because current major cities in Korea exhibit similarly low levels of $\mathrm{SO}_{2}$, we assumed that it does not act as a pollutant restricting lichen distribution in other cities as well.

The increase in $\mathrm{NOx}$, including $\mathrm{NO}_{2}$, influences many lichens. For example, since approximately 20 years ago, acidophilic lichens have been decreasing in the Netherlands, most likely due to an increase in $\mathrm{NOx}$ or $\mathrm{NH}_{3}$ (van Dobben and ter Braak 1998, 1999, van Herk et al. 2003). When $\mathrm{NO}_{2}$ concentration is $>0.019$ ppm only tolerant species survive, and lichen species richness will decrease further (Davies et al. 2007). In Seoul, yearly mean concentrations of $\mathrm{NO}_{2}$ have increased by 1.3 times from 1989 to 2009, reaching $0.035 \mathrm{ppm}$. This is higher than the 0.019 ppm suggested by Davies et al. (2007) or the 0.03 ppm air quality standard in Korea. $\mathrm{NO}_{2}$ in ICGs contribute greatly to such a high $\mathrm{NO}_{2}$ concentration (3-year mean for ICGs and OCGs was $0.038 \mathrm{ppm}$ vs. $0.015 \mathrm{ppm}$ ). Additionally, the speed at which $\mathrm{NO}_{2}$ increased was much greater in ICGs than in OCGs.

Tolerant species and/or nitrophilic species that belong to Candelariaceae, Physciaceae, and Teloschistaceae have been found in London (Davies et al. 2007). Four species belonging to Candelariaceae and Physciaceae were also found in Seoul in 2010. Of these four species, Candelaria concolor (Perlmutter 2010) and Phaeophyscia rubropulchra are nitrophilic species (Geiser and Neitlich 2007, Lawrey 2010). In particular, C. concolor, which appeared mostly in ICGs and therefore had low $Q$ values, is a tolerant species that occupies lichen desert edges (Conti and Cecchetti 2001). The other two species (Phaeophyscia hispidula and Physciella melanchra) found in ICGs are also likely to be nitrophilic species and must be studied further. However, the more surprising result is that M. aurulenta, P. rudecta, and P. rubropulchra, which coexist with other species in presumably relatively clean OCGs, are nitrophilic species (Lawrey 2010). Finding nitrogen bioindicators throughout Seoul may indicate that NOx concentration is quite high in all areas from the city center to outer Seoul.

Lichen species diversity decreases linearly with an increase in NOx (Davies et al. 2007). Increases in bark acidity (van Herk et al. 2003) or nutrient accumulation in bark (Davies et al. 2007) may contribute to a reduction in species diversity. In this study, four species abundant in ICGs comprised 101 of the 133 samples. If we assume that sampling efforts did not differ greatly at each site, such observations show that a few nitrophilic species are dominant in Seoul's high $\mathrm{NO}_{2}$ environment. If acidophilic species are under stress of $\mathrm{NH}_{3}$ (Jovan and McCune 2005) or NOx (Larsen et al. 2007) deposition, acidophilic species in Gwanaksan such as C. chlorophaea and C. macilenta (Gombert et al. 2004) may decline further. According to Geiser and Neitlich (2007), it may be difficult to identify the direct effects of $\mathrm{NO}_{2}$, because $\mathrm{SO}_{2}$ and $\mathrm{NO}_{2}$ are often positively correlated with each other. However, this appears not to be the case in Seoul, considering the drastic decrease in $\mathrm{SO}_{2}$ and considerable increase in $\mathrm{NO}_{2}$.

$\mathrm{O}_{3}$ is a secondary pollutant that is generated from a photochemical reaction between NOx and volatile organic compounds (VOC) (Haagen-Smit 1952). The amount of 
$\mathrm{O}_{3}$ in Seoul has steadily increased from $0.008 \mathrm{ppm}$ in 1989 to $0.021 \mathrm{ppm}$ in 2009 but is still below the air quality standard. Although Korea restricts $\mathrm{O}_{3}$ to a mean of $0.1 \mathrm{ppm} / \mathrm{h}$ or a mean of $0.06 \mathrm{ppm} / 8 \mathrm{~h}$, other countries have additional restrictions limiting the number of days the two aforementioned means rise above these levels (Seoul Metropolitan Government 2010). Considering the destructive effects of $\mathrm{O}_{3}$ on health and ecology, similar rules may have to be implemented in Korea. In this study, we only considered the yearly means of $\mathrm{SO}_{2}, \mathrm{NO}_{2}$, and $\mathrm{O}_{3}$ when analyzing the spatial and temporal patterns of lichen distribution. This is considered a limitation, because it is difficult to fully understand all the effects air pollutants cause with their yearly means, when their effects change seasonally and even daily. It is also notable that an increase in $\mathrm{O}_{3}$ was much greater in OCGs than in ICGs, which are exposed to a greater amount of automobile exhaust and other combustion activities (recent 3-year means, $0.019 \mathrm{ppm}$ vs. $0.034 \mathrm{ppm}$ ). If the amount of biogenic VOCs (BVOCs) released by forests is 10 times greater (Middleton 1995) than anthropogenic petrochemical production and use, and BVOCs are more reactive than anthropogenic VOCs (Stockwell and Kuhn 1998), it is possible that OCGs in Seoul have a greater concentration of $\mathrm{O}_{3}$ than that of the ICGs. However, despite the importance of BVOCs to oxidizing power of the atmosphere and greenhouse gases and differences in BVOC emission among plant species (e.g., Lim et al. 2011), studies on BVOC in Korea are still in the initial stages. Although it is known that $\mathrm{O}_{3}$ level does not exert a great influence on lichen diversity (McCune 1988, Nali et al. 2007), several lichen species are sensitive to SOx, NOx, and $\mathrm{O}_{3}$ (Sigal and Nash 1983, Conti and Cecchetti 2001, Lovett et al. 2009). For example, $0.1 \mathrm{ppm} \mathrm{O}_{3}$ causes a 50\% reduction in photosynthesis of Flavoparmelina caperata (Rose and Nash 1983). Considering that $\mathrm{O}_{3}$ is steadily increasing, it is important to assess the influence of both BVOCs and $\mathrm{O}_{3}$ on lichens.

The distribution of lichens in Seoul has changed greatly in the past 35 years. In this study, we have been able to deduce the following three results. First, in 2010, the lichen composition and species richness were different between ICGs and OCGs in Seoul. Second, although the species composition was different, this study and previous studies agree in terms of the linear trend between species richness and the distance from the city center. Third, $\mathrm{SO}_{2}$ is no longer a limiting factor for lichen existence in ICGs and OCGs. Instead, $\mathrm{NO}_{2}$, whose concentration has steadily increased in the past decades, appears to affect species composition and richness. Unlike $\mathrm{SO}_{2}$ or $\mathrm{NO}_{2}, \mathrm{O}_{3}$ level was much higher in OCGs. However, we could not directly relate $\mathrm{O}_{3}$ to lichen distribution. Diverse approaches using fumigation experiments, factorial designs incorporating multiple pollutants at once, and long-term monitoring are necessary to identify the importance of lichens to an air quality rating system and to evaluate the health of urban, and suburban areas, as well as forests.

\section{ACKNOWLEDGMENTS}

This work is in memory to our teacher, the late professor Choon Min Kim, who started research on lichens 35 years ago when almost no considered the small and ungraceful lichens. This work could not have even been initiated without the foresight of professors Choon Min Kim and Hee Sun Lee, both of whom we respect greatly. We also deeply thank lichen systematists whose help to identify the lichen species was essential for completing this project.

\section{LITERATURE CITED}

Asahina Y. 1937. Lichenologische Notizen (IX). J Jpn Bot 13: 315-321.

Bates JW, Bell JNB, Farmer AM. 1990. Epiphyte recolonization of oaks along a gradient of air pollution in southeast England, 1979-1990. Environ Pollut 68: 81-99.

Bates JW, Bell JNB, Massara AC. 2001. Loss of Lecanora conizaeoides and other fluctuations of epiphytes on oak in S.E. England over 21 years with declining $\mathrm{SO}_{2}$ concentrations. Atmos Environ 35: 2557-2568.

Brodo IM, Sharnoff SD, Sharnoff S. 2001. Lichens of North America. Yale University Press, New Haven, CT.

Chu EY, Kim JK. 1998. Estimation of air pollution using epiphytic lichens on forest trees around Ulsan industrial complex. J Korean For Soc 87: 404-414.

Conti ME, Cecchetti G. 2001. Biological monitoring: lichens as bioindicators of air pollution assessment: a review. Environ Pollut 114: 471-492.

Culberson CF. 1972. Improved conditions and new data for the identification of lichen products by a standardized thin-layer chromatographic method. J Chromatogr 72: 113-125.

Davies L, Bates JW, Bell JNB, James PW, Purvis OW. 2007. Diversity and sensitivity of epiphytes to oxides of nitrogen in London. Environ Pollut 146: 299-310.

de Bakker AJ. 1989. Effects of ammonia emission on epiphytic lichen vegetation. Acta Bot Neerl 38: 337-342.

Eversman S. 1978. Effects of low-level $\mathrm{SO}_{2}$ on Usnea hirta and 
Parmelia chlorochroa. Bryologist 81: 368-377.

Geiser LH, Neitlich PN. 2007. Air pollution and climate gradients in western Oregon and Washington indicated by epiphytic macrolichens. Environ Pollut 145: 203-218.

Gombert S, Asta J, Seaward MRD. 2004. Assessment of lichen diversity by index of atmospheric purity (IAP), index of human impact (IHI) and other environmental factors in an urban area (Grenoble, southeast France). Sci Total Environ 324: 183-199.

Haagen-Smit AJ. 1952. Chemistry and physiology of Los Angeles smog. Ind Eng Chem 44: 1342-1346.

Hale ME. 1969. How to Know the Lichens. Wm. C. Brown Co., Dubuque.

Hauck M, Jung R, Runge M. 2001. Relevance of element content of bark for the distribution of epiphytic lichens in a montane spruce forest affected by forest dieback. Environ Pollut 112: 221-227.

Hawksworth DL, McManus PM. 1989. Lichen recolonization in London under conditions of rapidly falling sulphur dioxide levels, and the concept of zone skipping. Bot J Linn Soc100: 99-109.

Hawksworth DL, Rose F. 1970. Qualitative scale for estimating sulphur dioxide air pollution in England and Wales using epiphytic lichens. Nature 227: 145-148.

Henderson-Sellers A, Seaward MRD. 1979. Monitoring lichen reinvasion of ameliorating environments. Environ Pollut 19: 207-213.

Hur JS, Kim PG. 2000. Investigation of lichen species as a biomonitor of atmospheric ozone in 'Backwoon' mountain, Korea. J Korean For Soc 89: 65-76. (in Korean)

Jovan S, McCune B. 2005. Air-quality bioindication in the greater Central Valley of California, with epiphytic macrolichen communities. Ecol Appl 15: 1712-1726.

Ka KH, Park H, Ryoo CI. 1997. Lichen flora of Ullung Island (I): Graphis and Pyrenula genera. Korean J Mycol 25: 7784. (in Korean)

Kim CM. 1991. The distribution of lichens in relation to sulphur dioxide in the urban and industrial areas. J Nat Acad Sci Nat Sci Ser 30: 47-71. (in Korean)

Kim CM, Lee HS. 1975. Quantitative studies on the distribution of corticolous lichens in Korea. Korean J Bot 18: 3844. (in Korean)

Kim JH, Kang SK. 2001. Estimation of air pollution by lichens in Chongju. J Korean Geogr Soc 36: 313-328. (in Korean)

Kim JK, Lee CK, Lee JH, Park EH, Oh KC. 2004. Distribution of epiphytic lichens around thermoelectric power plant. Korean J Ecol 27: 121-126. (in Korean)

Korea Meteorological Administration. 2001. Climatological Normals of Korea (1971-2000). Korea Meteorological Administration, Seoul. (in Korean)
Larsen RS, Bell JNB, James PW, Chimonides PJ, Rumsey FJ, Tremper A, Purvis OW. 2007. Lichen and bryophyte distribution on oak in London in relation to air pollution and bark acidity. Environ Pollut 146: 332-340.

Laundon JR. 1970. London's lichens. Lond Nat 49: 20-69.

Lawrey JD. 2010. Lichen biomonitoring in National Capital Region: lichens as bioindicators of air pollution. George Mason University, Virginia. http://mason.gmu. edu/ jlawrey/CUE/sensitivity. Accessed 24 July 2011.

LeBlanc F, De Sloover J. 1970. Relation between industrialization and the distribution and growth of epiphytic lichens and mosses in Montreal. Can J Bot 48: 1485-1496.

Lee CK, Koo CD, Ka KH. 1993. Development of techniques for air pollution monitoring using lichens. In: Impacts of Environmental Pollution on Forest Ecosystems (I) (Ministry of Science and Technology, ed). Ministry of Science and Technology, Gwacheon, pp 73-95. (in Korean)

Lee CK, Koo CD, Ka KH. 1994. Development of techniques for air pollution monitoring using lichens. In: Impacts of Environmental Pollution on Forest Ecosystems (II) (Ministry of Science and Technology, ed). Ministry of Science and Technology, Gwacheon, pp 93-127. (in Korean)

Lim YJ, Armendariz A, Son YS, Kim JC. 2011. Seasonal variations of isoprene emissions from five oak tree species in East Asia. Atmos Environ 45: 2202-2210.

Lovett GM, Tear TH, Evers DC, Findlay SEG, Cosby BJ, Dunscomb JK, Driscoll CT, Weathers KC. 2009. Effects of air pollution on ecosystems and biological diversity in the eastern United States. Ann N Y Acad Sci 1162: 99-135.

Marmor L, Tõrra T, Saag L, Randlane T. 2011. Effects of forest continuity and tree age on epiphytic lichen biota in coniferous forests in Estonia. Ecol Indic 11: 1270-1276.

McCune B. 1988. Lichen communities along $\mathrm{O}_{3}$ and $\mathrm{SO}_{2}$ gradients in Indianapolis. Bryologist 91: 223-228.

Middleton P. 1995. Sources of air pollutants. In: Composition, Chemistry, and Climate of the Atmosphere (Singh HB, ed). Van Nostrand Reinhold, New York, pp 88-119.

Ministry of Environment. 2010. Annual Report of Air Quality in Korea 2009. Ministry of Environment of Korea, Gwacheon. (in Korean)

Moon KH. 1998. Lichen survey. In: A Study of the Effects of Urban Pollution on the Forest Ecosystem and Countermeasures in Bukhansan National Park (Korea National Park Service, ed). Korea National Park Service, Seoul, pp 115-126. (in Korean)

Nali C, Balducci E, Frati L, Paoli L, Loppi S, Lorenzini G. 2007. Integrated biomonitoring of air quality with plants and lichens: a case study on ambient ozone from central 
Italy. Chemosphere 67: 2169-2176.

Nash TH 3rd. 2008. Lichen sensitivity to air pollution. In: Lichen Biology (Nash TH 3rd, ed). Cambridge University Press, Cambridge, pp 299-314.

Nimis PL, Castello M, Perotti M. 1990. Lichens as biomonitors of sulphur dioxide pollution in La Spezia (Northern Italy). Lichenologist 22: 333-344.

Nylander W. 1866. Hypochlorite of lime and hydrate of potash, two new criteria in the study of lichens. J Linn Soc Lond Bot 9: 358-365.

Oh KS, Chung HB. 2007. The influence of urban development density on air pollution. J Korea Plann Assoc 42: 197-210. (in Korean)

Park YS. 1990. The macrolichen flora of South Korea. Bryologist 93: 105-160.

Perlmutter GB. 2010. Bioassessing air pollution effects with epiphytic lichens in Raleigh, North Carolina, U.S.A. Bryologist 113: 39-50.

Rose CI, Hawksworth DL. 1981. Lichen recolonization in London's cleaner air. Nature 289: 289-292.

Rose LJ, Nash TH 3rd. 1983. Effect of ozone on gross photosynthesis of lichens. Environ Exp Bot 23: 71-77.

Seaward MRD. 1997. Urban deserts bloom: a lichen renaissance. Bibl Lichenol 67: 297-309.

Seoul Metropolitan Government. 2010. 2009 Environment of Seoul. Seoul Metropolitan Government, Seoul. (in Korean)

Sigal LL, Nash TH 3rd. 1983. Lichen communities on conifers in southern California mountains: an ecological survey relative to oxidant air pollution. Ecology 64: 1343-1354.
Stockwell WR, Kuhn M. 1998. Study of the effect of biogenic VOC emissions on regional ozone production and the implications for VOC or NOx control. Proceedings of the Air and Waste Management Association 91st Annual Meeting and Exhibition; 1998 June 14-18; San Diego, CA. Air and Waste Management Association, Pittsburgh, PA.

Sugiyama K, Kurokawa S, Okada G. 1976. Studies on lichens as a bioindicator of air pollution. I. Correlation of distribution of Parmelia tinctorum with $\mathrm{SO}_{2}$ air pollution. Jpn J Ecol 26: 209-212.

van Dobben HF, ter Braak CJF. 1998. Effects of atmospheric $\mathrm{NH}_{3}$ on epiphytic lichens in the Netherlands: the pitfalls of biological monitoring. Atmos Environ 32: 551-557.

van Dobben HF, ter Braak CJF. 1999. Ranking of epiphytic lichen sensitivity to air pollution using survey data: a comparison of indicator scales. Lichenologist 31: 27-39.

van Herk CM, Mathijssen-Spiekman EAM, de Zwart D. 2003. Long distance nitrogen air pollution effects on lichens in Europe. Lichenologist 35: 347-359.

Yoo SS. 2008. Research of air quality improvement in Seoul through temporal and spatial variation analysis. $\mathrm{PhD}$ Dissertation. University of Konkuk, Seoul, Korea. (in Korean)

Yoshimura I. 1994. Lichen Flora of Japan in Color. $6^{\text {th }}$ ed. Hoikusha, Osaka.

Yu JH, Ka KH, Park H. 1995. Air pollution effects on soil chemical properties, lichens, denitrifying and sulfurreducing bacteria around the Yeochun industrial estate. J Korean For Soc 84: 178-185. (in Korean) 